\title{
Effect of IBA and Sucrose on Performance of Cuttings in Pear cv. Patharnakh
}

\author{
Amit Dhand, Vipanpreet Kaur and Amarjeet Kaur* \\ Department of Horticulture, Khalsa College, Amritsar-143001, India \\ *Corresponding author
}

\section{A B S T R A C T}

\section{Keywords}

Cuttings, IBA,

Quick dip, Pear,

Patharnakh,

Survival, Sprouting,

Sucrose

Article Info

Accepted:

07 June 2019

Available Online:

10 July 2019
In order to study the effect of IBA and sucrose on performance of cuttings in pear cv. Patharnakh an investigation was conducted at the nursery of Department of Horticulture, Khalsa College, Amritsar during 2018-2019. Eleven treatments were used comprising of IBA (1000, 1500, 2000, 2500 and $3000 \mathrm{ppm})$ and sucrose $(1000,1500,2000,2500$ and $3000 \mathrm{ppm})$ by quick dip method along with control. The results of the investigation indicated that IBA $(2500 \mathrm{ppm})$ proved to be the best in terms of minimum days to first sprouting (23.15), maximum sprouting percentage $(69.72 \%)$, survival percentage (47.29\%), number of roots per cutting (5.00), root length $(11.50 \mathrm{~cm})$ while maximum number of shoots per cutting (4.66) and average shoot diameter $(2.11 \mathrm{~cm})$ were indicated in the cuttings treated with sucrose $(2500 \mathrm{ppm})$ respectively.

\section{Introduction}

Pear is undoubtedly one of the most ancient ubiquitous of all the temperate fruits and rank $2^{\text {nd }}$ next only to apple in the deciduous fruits of the world (Chadha, 2001). The pear spp. belongs to the family Rosaceae and sub family Maloideae (Dhillon, 2013). Presently pear is next to apple in importance acreage, production and varietal wealth among temperate fruits in India. It is less winter hardy due to which it can be grown in a wide range of climatic conditions, even in the warmer climates of subtropical regions. Pear fruit is said to be consumed in diets because of low calorific value. It has high nutritional value with reasonable amounts of vitamins $\mathrm{A}, \mathrm{B}, \mathrm{B}_{2}$, $\mathrm{C}$ and minerals like $\mathrm{Na}, \mathrm{K}, \mathrm{P}, \mathrm{Ca}, \mathrm{Mg}$ and $\mathrm{Fe}$. It has a lot of fiber, giving excellent results in the treatment of constipation and intestine inflammation, fiber reduces the cholesterol in body and there by protects from various heart diseases. It also cures kidney stones and cystitis (Silva et al., 2014). Its juice is sometimes used as the first juice introduced to infants (Vadivel and Janardhanam, 2005). Antioxidants present in them help to fight against many health problems improving immunity. Anti-carcinogen glutathione and antioxidants present in pears help in 
controlling the blood pressure. Due to the presence of grit cells in pear fruits regular consumption of it offers protection against colon cancer. Pear is consumed fresh, canned, as juice dried. The juice can also be used in jellies and jams, usually in combination with other fruits or berries. Pear leaves were smoked in Europe before tobacco was introduced. In Patharnakh in order to have uniform and true to type planting material of hard wood cuttings is used for propagation. The cuttings are prepared during December from juvenile shoots and are kept for callusing for about a month and are planted in the nursery. True to type planting materials are scare within commercial growing belt. Availability of pear plants through certified nursery is also meagre. Treatment of cuttings with different growth hormones promotes rooting (Dhillon 2013).

It has been reported that root promoting hormones play an important role in the success of rooting of cuttings (Siddiqui and Hussain 2007). They promote the cell division of the meristematic tissues, promotes callus formation, root formation and bud formation. Hardwood cuttings when planted with IBA $500 \mathrm{ppm}$, resulted in maximum number of leaves (Singh, 2014). IBA and PHB (500-1500 ppm) when applied together generated highest rooting and survival percentage (Ram et al., 2005). For effective rooting of cutting it is very important that the stem has sufficient carbohydrate reserve so as to sustain it during the period before the cutting start synthesizing its own photosynthate.

High carbohydrate levels in shoots are thought to be conducive to root formation (Hartmann and Kester, 1990). Carbohydrates may serve as a source of energy and of carbon for the synthesis of other substances essential for root initiation. Starch accumulation at the base of avocado (Persea americana) cuttings was highly correlated with the number of cuttings that rooted (Kesari et al., 2010). Hence, the addition of carbohydrate source like starch or sucrose would therefore improve the rooting efficiency. Keeping in view the importance of it, the present study was initiated to find out the suitable growth regulator for cuttings to produce better and quicker rooting through the use of varying concentrations of different growth regulators.

\section{Materials and Methods}

The present investigations were carried out in the nursery of Department of Horticulture, Khalsa College, Amritsar during the year 2018-2019 to examine the effect of IBA and sucrose on performance of pear cuttings cv. Patharnakh. The cuttings were taken from healthy uniform sized branches of Patharnakh growing in the nursery of Department of Horticulture, Khalsa College, during January. The shoots selected for preparation of cuttings were healthy and free from malady. Cuttings of about pencil thickness and $20 \mathrm{~cm}$ in length having 3-6 buds were prepared with a slanting cut given at the upper side and a round cut at the lower end of the cutting. The cuttings were treated by the soak method in IBA and Sucrose.

There were 11 treatments comprising of IBA and Sucrose each with concentrations of 1000 , 1500, 2000, 2500 and 3000 ppm and control. $1000 \mathrm{ml}$ growth regulator solution of appropriate concentration was taken in beaker and a unit of 25 cuttings was placed in each approximately $1 \frac{1 / 2}{2}$ inch of the basal ends of cuttings dipped in solution for upto 2 minutes. In control, the cuttings were dipped in distilled water for the same period of time. After that data on rooting parameters like days to sprouting, sprouting percentage, survival percentage, root number, root length, shoot number were recorded and analysed with Completely Randomized Block Design. 


\section{Results and Discussion}

\section{Days taken to sprouting}

It was observed that the hardwood cuttings treated with 2500 ppm IBA concentrations took minimum duration in sprouting (23.15 days) where as these had taken longest duration (47.21 days) in control. Earliness in sprouting might be due to the fact that there was better utilization of stored carbohydrates, nitrogen and other factors with help of growth regulators (Chandramouli, 2001).

Evidence suggests that auxin increased rooting percentages, shortened the rooting period and ensured improved uniformity in plants (Hartmann et al., 2011).

\section{Sprouting percentage $(\%)$}

The cuttings treated with $2500 \mathrm{ppm}$ IBA gave highest sprouting $(69.72 \%)$ while the least (35.78\%) was recorded in $\mathrm{T}_{11}$ (Control). Evidence suggests that auxins increased rooting percentages, shortened the rooting period and ensured improved uniformity in plants (Hartmann et al., 2011).

The increase in number of sprouts and sprout might be due to the better utilization of stored carbohydrates, nitrogen and other factors with the help of growth regulators (Sinha et al., 2014). Application of the auxins might have caused hydrolysis and translocation of carbohydrates and nitrogeneous substances at the base of cuttings and resulted in accelerated cell division and cell elongation (Singh et al., 2015).

It also has been found to enhance the histological features like formation of callus and tissue and differentiation of vascular tissue. The research findings of Kurd et al., (2010), Thota (2012) are also in line with the present findings (Table 1).

\section{Survival percentage $(\%)$}

The studies on the survival percentage of cuttings revealed that maximum survival (68.34\%) was in $\mathrm{T}_{4}$ as compared to the rest of the treatments and the least (32.75\%) was under control.

The superiority of treated cuttings regarding the survival can be attributed to better start and root growth. The better start might have facilitated absorption of nutrients and moisture from soil and better growth developed capacity to withstand for a longer period (Ram et al., 2005). These results are also supported by Ishtiaq et al., (1989) who observed the positive association relating to root formation and bud sprout in peach cultivar Peshawar local.

These results supported the findings of Singh et al., (2011) in cuttings of Bougainvillea, Melgarejo et al., (2008) also showed that in pomegranate, the increment in the percentage of cuttings that rooted occurred in most of the clones using low IBA application concentration. The highest survival percentage with IBA was observed on full-leaf cuttings of Camellia sinensis (L.) Kuntze by Zenginbal et al., (2014) and in Bougainvillea stem cuttings by Sultana et al., (2016).

\section{Number of roots per cutting}

It is clear from the data that the number of roots (5.00) were significantly higher in 2500ppm IBA closely followed by (4.98) in $\mathrm{T}_{9}$ (2500 ppm Sucrose) as compared to the rest of the treatments while the lowest (1.00) roots were found in $\mathrm{T}_{11}$ (control). This pertains to the fact that the auxins promoted cell division and their elongation led to differentiation of cambial initials into root primordia and in the mobilization of reserve food material to sites of root initiation there by giving higher number of roots per cutting (Sharma 1999). 
Table.1 Effect of IBA and sucrose on sprouting and survival (\%) in pear cv. Patharnakh

\begin{tabular}{|c|c|c|c|}
\hline Treatments & $\begin{array}{l}\text { Days taken to } \\
\text { sprouting }\end{array}$ & $\begin{array}{c}\text { Sprouting } \\
\text { percentage (\%) }\end{array}$ & $\begin{array}{c}\text { Survival percentage } \\
(\%)\end{array}$ \\
\hline$T_{1}-$ IBA 1000 ppm & 36.21 & 50.97 & 47.29 \\
\hline$T_{2}$ IBA $1500 \mathrm{ppm}$ & 33.29 & 53.86 & 51.97 \\
\hline$T_{3}$ - IBA 2000 ppm & 27.31 & 60.98 & 63.42 \\
\hline$T_{4}-$ IBA $2500 \mathrm{ppm}$ & 23.15 & 69.72 & 68.34 \\
\hline$T_{5}$ IBA 3000 ppm & 25.19 & 65.15 & 64.72 \\
\hline$T_{6^{-}}$Sucrose $1000 \mathrm{ppm}$ & 36.78 & 50.57 & 48.62 \\
\hline $\mathrm{T}_{7}-$ Sucrose $1500 \mathrm{ppm}$ & 33.19 & 54.32 & 52.86 \\
\hline$T_{8^{-}}$Sucrose $2000 \mathrm{ppm}$ & 28.31 & 57.21 & 53.74 \\
\hline $\mathrm{T}_{9}$ - Sucrose $2500 \mathrm{ppm}$ & 26.40 & 62.74 & 60.65 \\
\hline$T_{10^{-}}$Sucrose $3000 \mathrm{ppm}$ & 27.11 & 61.99 & 59.32 \\
\hline $\mathbf{T}_{11^{-}}$Control & 47.21 & 35.78 & 32.75 \\
\hline CD (5\%) & 0.01 & NS & 0.02 \\
\hline CV (5\%) & 0.03 & 0.02 & 0.20 \\
\hline
\end{tabular}

Table.2 Effect of IBA and sucrose on root and shoots parameter in pear cv. Patharnakh

\begin{tabular}{|c|c|c|c|c|}
\hline Treatments & Root number & $\begin{array}{l}\text { Root length } \\
\text { (cm) }\end{array}$ & Shoot number & $\begin{array}{c}\text { Shoot } \\
\text { diameter }(\mathbf{c m})\end{array}$ \\
\hline $\mathrm{T}_{1}$ - IBA $1000 \mathrm{ppm}$ & 1.33 & 6.93 & 1.20 & 0.87 \\
\hline $\mathrm{T}_{2}$ - IBA $1500 \mathrm{ppm}$ & 1.79 & 8.12 & 1.66 & 0.98 \\
\hline T $_{3}$ - IBA 2000 ppm & 4.33 & 9.81 & 2.01 & 1.11 \\
\hline T $_{4}-$ IBA 2500 ppm & 5.00 & 11.50 & 3.73 & 1.89 \\
\hline$T_{5}-$ IBA $3000 \mathrm{ppm}$ & 4.00 & 10.96 & 3.00 & 1.78 \\
\hline$T_{6}-$ Sucrose 1000 ppm & 1.21 & 5.26 & 2.00 & 0.62 \\
\hline$T_{7}-$ Sucrose $1500 \mathrm{ppm}$ & 1.67 & 8.50 & 3.20 & 0.85 \\
\hline$T_{8}$ - Sucrose 2000 ppm & 2.76 & 9.41 & 4.33 & 1.96 \\
\hline $\mathrm{T}_{9}$ - Sucrose $2500 \mathrm{ppm}$ & 4.98 & 10.12 & 4.66 & 2.11 \\
\hline $\mathbf{T}_{10^{-}}$Sucrose $3000 \mathrm{ppm}$ & 4.31 & 9.91 & 2.78 & 1.42 \\
\hline $\mathbf{T}_{11^{-}}$Control & 1.00 & 3.29 & 1.00 & 0.88 \\
\hline CD (5\%) & 1.00 & 0.02 & 0.08 & 0.02 \\
\hline CV $(5 \%)$ & 1.83 & 0.14 & 1.65 & 0.75 \\
\hline
\end{tabular}

It also might have been due to the increased cell division and their differentiation under the influence of rooting chemicals, enhanced hydrolysis of nutritional reserves resulting into the increased root formation zone. These results are supported with the findings of Rufato and Kersten (2000) in Esmeralda peach, Swedan et al., (1993) in cuttings of plum, Mehraj et al., (2013) in Bougainvillea spectabilis and Shukla et al., (2010) in peach. Kaur (2017) and Mehta et al., (2016) also reported the same in peach and pear cuttings. There was a reverse tendency in average number of roots with increasing concentrations of IBA. This might be due to the reason that auxins help in rooting 
behaviour only upto certain limit. If higher concentrations beyond tolerate limits are given, it may result in unfavourable conditions, leading to toxicity of exogeneously applied substances.

\section{Root length $(\mathrm{cm})$}

The data clearly indicated that significantly maximum length of root $(11.50 \mathrm{~cm})$ was recorded with $\mathrm{T}_{4}$ (IBA $2500 \mathrm{ppm}$ ) while the least root length was of $11.18 \mathrm{~cm}$ was under the control. Evidence suggests that auxins might have increased rooting and ensured length of roots as the root elongation stage is very responsive to auxin concentration and it might be exhibited by the higher concentrations (Hartmann et al., 2002). Auxin concentration is most important for root elongation which might be inhibited by the increasing levels of exogenous auxins in the rooting media (Baker and Wetzstein, 1994). Zenginbal et al., (2014) reported the same in Camellia sinensis (L.) O. Kuntze, Melgarejo et al., (2008), Saroj et al., (2008), Polat and Caliskan (2009) in pomegranate and Kaur (2017) in peach (Table 2).

\section{Number of shoots per cutting}

The data pertaining to the number of shoots depicted that the different concentrations of IBA and Sucrose had little significance on number of shoots produced from cuttings. It was clear that shoot number increased with increase in the concentration of growth regulators up to a limit. The maximum number of shoots (4.66) was registered from the cuttings treated with sucrose $2500 \mathrm{ppm}$ $\left(\mathrm{T}_{9}\right)$ and $(4.33)$ in sucrose $2000 \mathrm{ppm}\left(\mathrm{T}_{8}\right)$ and the minimum (1.00) were noticed in untreated plants. The more number of shoot formation might be due to the vigorous root system which increased the nutrient uptake which in turn affected the cell division in the vascular cambium, cell expansion and control of differentiation into different types of cambial resulting in increase in number of shoots (Devi et al., 2016). The better performance with the use of sucrose could be explained by the larger carbon skeleton provided by the carbohydrate present within it, resulting in higher availability of biosynthetic building blocks (Correa et al., 2005). The results are in line with the findings of Dey et al., (2017) in karonda.

\section{Average shoot diameter $(\mathrm{cm})$}

According to the data regarding shoot diameter as influenced by IBA and sucrose, the maximum shoot diameter $(2.11 \mathrm{~cm})$ was recorded in the treatment $\mathrm{T}_{9}$ (sucrose 2500 ppm) while the minimum $(0.81 \mathrm{~cm})$ was in the untreated cuttings of pear. The maximum shoot diameter observed in cuttings, might be attributed to more number of roots because auxins favoured cell division and their elongation and helped in better root development thereby resulting in better shoots with more shoot diameter.

It was also due to the higher cell activity, more synthesized food material and photosynthates hence more shoots with more stem diameter (Devi et al., 2016). Also the growth of sprouts in terms of length and width is dependent upon the optimal balance of root and shoot ratio essential for absorption and translocation of moisture and nutrients (Shukla et al., 2010).

It can be concluded from the present study that the treatment of cuttings of pear cv. Patharnakh with IBA2500 ppm applied as quick dip was found to be the most efficacious in encouraging rooting parameters and invigorating the shoots leading to good shoot number, diameter of shoots. It also aided to the good sprouting and survival percentage. Hence, pear cv. Patharnakh can be propagated successfully through cuttings treated with IBA (2500 ppm). 


\section{References}

Baker CM and Wetzstein H (1994) Influence of auxin type and concentration on peanut somatic embryogenesis. Plant cell tissue organ culture 36:361-368.

Chadha KL (2001) Handbook of horticulture. ICAR, New Delhi.

Chandramouli H (2001) Influence of Growth regulators on the rooting of different types of cuttings in Burserapenicillata (DC). M.Sc (Agri.) Thesis, Univ of Agri Sci, Banglore.

Correa LDR, Paim DC, Schwambach J, FettNeto AG (2005) Carbohydrates as regulatory factors on the rooting of Eucalyptus saligna Smith and Eucalyptus globulus Labil. Plant Growth Regul: 45:63-73.

Devi J, Bakshi P, Wali VK, Kour K and Sharma $\mathrm{N}$ (2016) Role of auxin and dates of planting on growth of cuttings raised plantlets of phalsa (Grewia asiatica L.). The Bioscan 11: 535-537.

Dey K, Ghosh A, Mani A, Bauri FK and Dey AN (2017) Root generation of karonda cuttings in response to sucrose and IBA. $J$ Pharmacognosy and Phytochemistry 6:803-806.

Dhillon WS (2013) Fruit production in India. Narendra publishing house, New Delhi110006 (India).

Hartmann HT, Kester DE, Davies FT and Geneve RL (2011) Plant propagation: principles and practices. 8th Edition. São Paulo: Prentice-Hall 915.

Hartmann HT, Kester DE, Davis FT and Genev RL (2002) Plant Propagation: Principles and Practices. Prentice Hall, Englewood Cliffs 880.

Hartmann, H.T. and Kester, D.E. (1990). Plant propagation, principles and practices Fourth Ed., Prentice- Hill, INC Engleood Cliffs, New Jersy, USA.

Ishtiaq, M., Iftikhar, H. and Ayaz, M. (1989). Initiation of roots in peach rootstocks cvs. Peshawar Local and Nemaguard as affected by indole butyric acid. Sarhad $J$ Agri, 5:41-45.

Kaur S (2017). Evaluation of different doses of indole-3-butyric acid (IBA) on the rooting, survival and vegetative growth performance of hardwood cuttings of Flordaguard peach (Prunus persica L. Batch) J App and Nat Sci 9: 173 - 180.

Kesari, V., Krishnamachari, A. and Rangan, L. (2009). Effect of auxins on adventitious rooting from stem cuttings of candidate plus tree Pongamia pinnata (L.). A potential biodiesel plant Trees: Structure and Function, 23: 597-604.

Kurd AA, Khan SA, Shah BH and Khetran MA (2010) Effect of indole butyric acid (IBA) on rooting of olive stem cuttings. Pak $J$ Agric Res 23: 3-4

Mehraj, H., Shiam, I.H., Taufique, T., Shahrin, S. and Jamal Uddin, A.F.M. (2013). Influence of Indole-3-Butyric Acid (IBA) on sprouting and rooting potential of Bougainvillea spectabilis cuttings. Bangladesh Research Publications Journal, 9: 44-49.

Mehta NS, Bhatt SS, Kumar J, Kotiyal A and Dimri DC (2016). Effect of IBA on vegetative growth and multiplication rate in stem cuttings of pear rootstocks. HortFlora Res Spectrum5: 242-245.

Melgarejo P, Martinez J, Martinez J J and Sanchez M (2008) Preliminary survival experiments in transplanting pomegranate. In: Production, Processing and Marketing of Pomegranate in the Mediterranean region. Advances in Res and techn Zaragoza, CIHEAM Publication, Europe 163-167.

Polat AA and Caliskan O (2009) Effect of Indole Butyric Acid (IBA) on rooting of cutting in various pomegranate genotype Acta Hort (ISHS) 818: 187-192.

Ram RB, Kumar P and Kumar A (2005) Effect of IBA and PHB on regeneration of pomegranate (Punica granatum L.) through stem cuttings. New Agriculturalist 16: 113-122.

Rufato, L. and Kersten, E. (2000). Rooting of cuttings of peaches (Prunus persica (L.) 
Batsch) cv. Esmeralda and BR2 exposed to stratification and indole butyric acid. Revista Brasileira de Fruiticultura, 22: 191-194

Saroj P L, Awasthi O P, Bhargava R and Singh U V (2008) Standardization of pomegranate propagation by cutting under mist system in hot arid region. Indian J Horti 65: 25-30.

Sharma S (1999) Effect of type of cuttings IBA and time of planting on rooting of cuttings in pomegranate (Punica granatum L.) cv. Ganesh. M.Sc. Thesis GNDU Amritsar

Shukla HS, Tripathi VK, Awasthi RD and Tripathi AK (2010) Effect of IBA, PHB and Boron on rooting and shoot growth of hard wood stem cuttings of Peach. Int $J$ App Agri Res 5: 467.

Siddiqui MI and Hussain SA (2007) Effect of Indole butyric acid and types of cuttings on root initiation of Ficus hawaii. Sarhad J Agri23: 920-26.

Silva G J, Souza T M, Barbieri R L and de oliveira A C (2014) Origin, domestication and dispersing of pear. Adv in Agri: 8 .

Singh KK and Tomar YK (2015) Effect of planting time and Indole butyric acid levels on rooting of woody cuttings of Phalsa (Grewia asiatica L.) Horti Flora Res Spectrum 4:39-43.

Singh S and Singh KK (2014) Effect of various concentration of IBA and types of stem cuttings on the performance of rooting in Sweet Orange (C. sinensis L. osbeck) cv. Malta under mist. The Bioscan 11:903-06.
Singh, K.K., Rawat, J.M.S. and Tomar, Y.K. (2011). Influence of IBA on rooting potential of Torch Glory Bougainvillea glabra during winter season. Journal of Horticultural Science \& Ornamental Plants, 3: 162-165

Sinha NK, Kumar S, Santra P, Raja P and Mertia D (2014) Temporal growth performance of Indian myrrh (Commiphora wightii) raised by seedlings and cuttings from same genetic stocks in the extremely arid Thar desert of India. The Ecoscan 8: 241-244.

Sultana, Z., Akand, M.S.H. and Patwary, N.H. (2016). Root-ing performance of stem cuttings of three ornamental plants as influenced by growth regulators. International Journal of Natural and Social Sciences, 3(2): 38-45

Swedan, A.A., Edriss, M.H., Alhamed, A., Yusre, A. (1993). Root initiation in the plum rootstock Marianna and the promotive effects of co-factors. Egyptian Journal of Horticulture, 20(1): 43-55

Thota S, Madhavi K and Vani VS (2012) Effect of type of cuttings and IBA concentrations on the propagation of fig. Int J Tropical Agri 32: 89-94

Zenginbal, H., Haznedar, A. and Dolgun, O. (2014). Effects of Indole-3-Butyric Acid (IBA) and cutting type on rooting of Camellia sinensis (L.) O. Kuntze. American Journal of Experimental Agriculture, 4(12): 1935-1943

\section{How to cite this article:}

Amit Dhand, Vipanpreet Kaur and Amarjeet Kaur. 2019. Effect of IBA and Sucrose on Performance of Cuttings in Pear cv. Patharnakh. Int.J.Curr.Microbiol.App.Sci. 8(07): 545-551. doi: https://doi.org/10.20546/ijcmas.2019.807.067 